\title{
SCANNING ELECTRON MICROSCOPY AND REPLICA STUDIES OF ARTICULAR SURFACES OF GUINEA-PIG SYNOVIAL JOINTS
}

\author{
BY \\ D. L. GARDNER AND D. WOODWARD \\ Division of Experimental Pathology, Kennedy Institute, London
}

Many attempts have been made during the past 20 years to explain the remarkable lubricating qualities of synovial fluid (Dowson, 1966-67; McCutcheon, 1966-7) but, until recently, relatively little attention has been paid to the precise threedimensional form of the articulating surfaces between which the fluid is interposed. Indeed, McCall (1968) stated that the literature contained no light microscope photographs of synovial joint surfaces. The advent of the scanning electron microscope has made the incident light microscope almost obsolete in this respect: the scanning microscope combines great depth of focus with the capacity to photograph large portions of tissue at low magnification. These properties have appealed to students of synovial joint function and observations from several centres have now begun to suggest some of the structural appearances which may be encountered at human joint surfaces.

It seemed equally important to learn more of the surface of the synovial joints of the common laboratory animals and, since the guinea-pig and rat were being used extensively in these laboratories for investigations of experimental arthritis, it was decided to define the appearances encountered when scanning electron microscopy was used to survey the main joints of these animals.

In the present paper a first investigation of the upper and lower femoral and upper tibial surfaces of the guinea-pig is reported. The photographs obtained by scanning electron microscopy are compared with those made with incident light and with replicas of the joint surfaces prepared by a 2-stage technique and viewed by conventional transmission electron microscopy.

\section{Material and Methods}

Normal male and female adult Heston guinea-pigs were killed by the administration of Nembutal and the hind limbs quickly dissected free from soft tissue. The femora and tibiae were divided $1.5 \mathrm{~cm}$. from the hip and knee joints respectively. Both ends of the femur and the upper end of the tibia were immediately plunged into cold, buffered 1 per cent. osmic acid (Palade) and allowed to fix for 2-3 hours. After passing to 70 per cent. ethyl alcohol, the material was further trimmed to remove unwanted bone before dehydration was completed by progression through alcohol. Some bone ends were mounted on specimen stubs with the exposed articular surfaces uppermost and coated with layers, first of carbon (about $20 \AA$ ) and second of gold/palladium alloy (about $1,000 \AA$ ) under a vacuum of $10^{-4} \mathrm{~mm}$. $\mathrm{Hg}$; other bone ends were studied after mounting but without coating.

Light Microscopy.-24 specimens were examined and photographed by means of Leitz reflection objectives mounted in an Ortholux microscope using low illumination levels to reduce high spots.

Scanning Electron Microscopy.-24 specimens selected from the 72 bone ends available from twelve dissected animals were placed in a Stereoscan instrument (Cambridge Instrument Company) and examined at ranges of magnification from 30 to $15,000 \times$.

Transmission Electron Microscopy.-Replicas of the articular surfaces were made by a 2-stage technique (Nalon, 1959; Kay, 1965) modified from the methods of Bradley (1954) and of Koonce and Berting (1956). Stanvis Necoloidine (B.D.H.) was applied to the surface and dried. Further applications were made to reinforce the original replica. The collodion cast was stripped from the surface and coated with a layer of carbon approximately 100-200 $\AA$ in thickness before backing the carbon-coated surface with gum Arabic. The collodion layer was dissolved away in amyl acetate and the carbon surface exposed in this way was shadowed with a gold/ palladium alloy. The gum was dissolved in water, the carbon replicas were floated on to copper grids, and the grids observed in an AEI EM6B electron microscope.

In a small number of instances the exposed joint surfaces were treated with hyaluronidase ("Hyalase") for 10-15 minutes before replicas were made. This technique was tested on normal joints and on the joint surfaces of animals with experimental hypersensitivity arthritis. 


\section{Results}

\section{Light Microscopy}

The limitations of incident light microscopy for the direct study of synovial joint surfaces were confirmed. Light sufficiently bright to permit observation gave reflection patterns which made visualization difficult; photography was only possible by long exposure at very low levels of illumination. Despite a limited depth of focus, a series of coarse dimples and of finer hollows and prominences was recognised (Fig. 1). The dimples appeared to be approximately $400 \mu$ in diameter; the small hollows were approximately $20-40 \mu$ in diameter and were arranged at random and were not orientated. They were not recognized with equal ease in all areas of the two joints. Although they were characteristic of the weight-bearing surface of the femur, they were less obvious at the margins of the tibial condyles and at the bottom of the grooved articulating surface of the femur.

\section{Scanning Electron Microscopy}

Photographs obtained with the scanning electron microscope confirmed the general surface pattern recorded by light microscopy (Figs 2 and 3). Broad, shallow dimples approximately $200-400 \mu$ in diameter covered the surface of the femur in all areas except that adjacent to the ligamentum teres. It was possible to photograph the whole femoral head in focus. At higher magnification (Fig. 3), a series of much smaller hollows and prominences was found superimposed on the pattern described above and having the same random arrangement. These smaller hollows measured approximately 20-30 $\mu$ in diameter. Their presence was occasionally

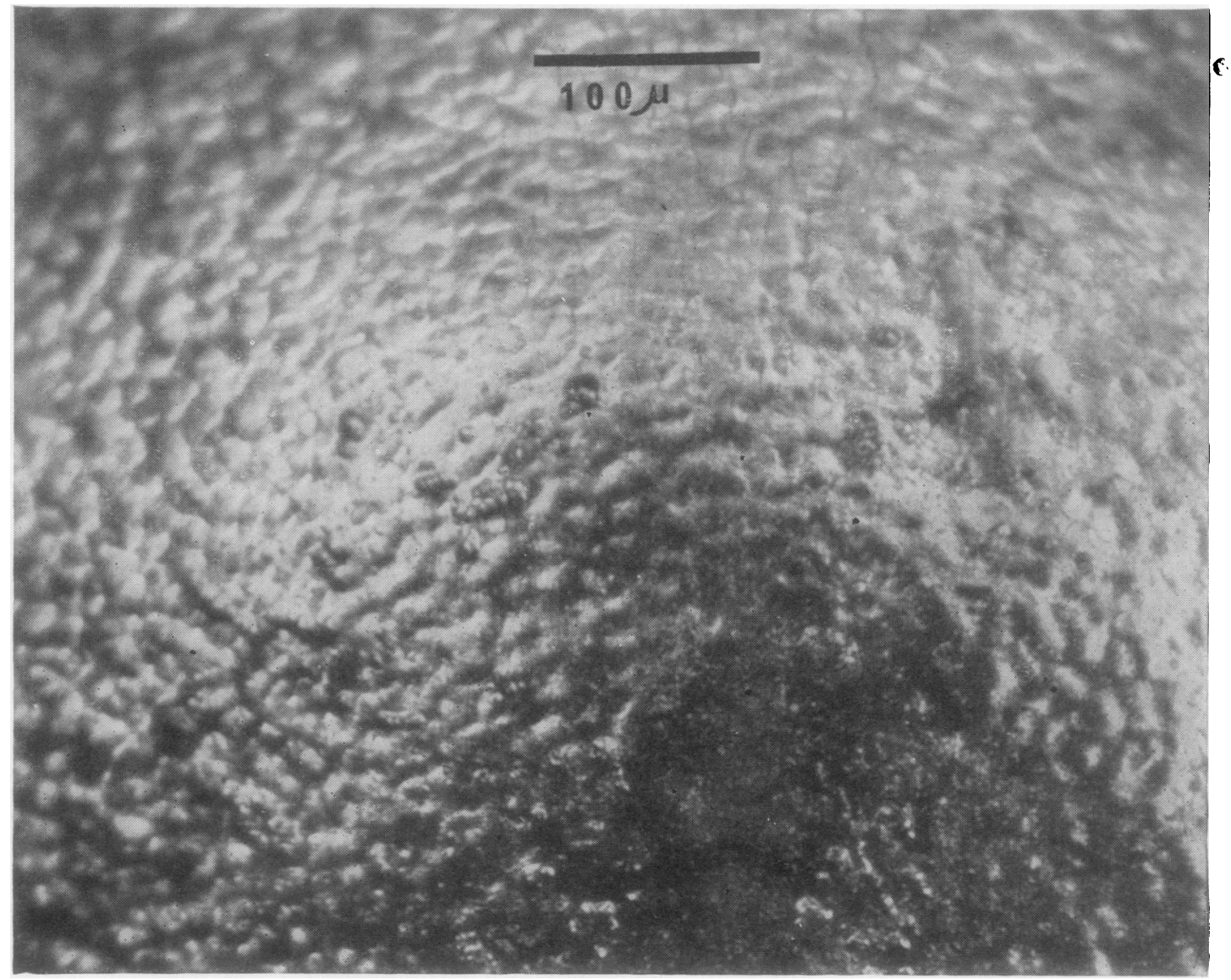

Fig. 1.-Femoral head. Incident light microscope view. The small prominences and hollows which cover the surface correspond with those detected by scanning electron microscopy (Fig. 3). The large dimples approximately $400 \mu$ diameter shown in Fig. 2 cannot easily be seen. $\times 270$. 


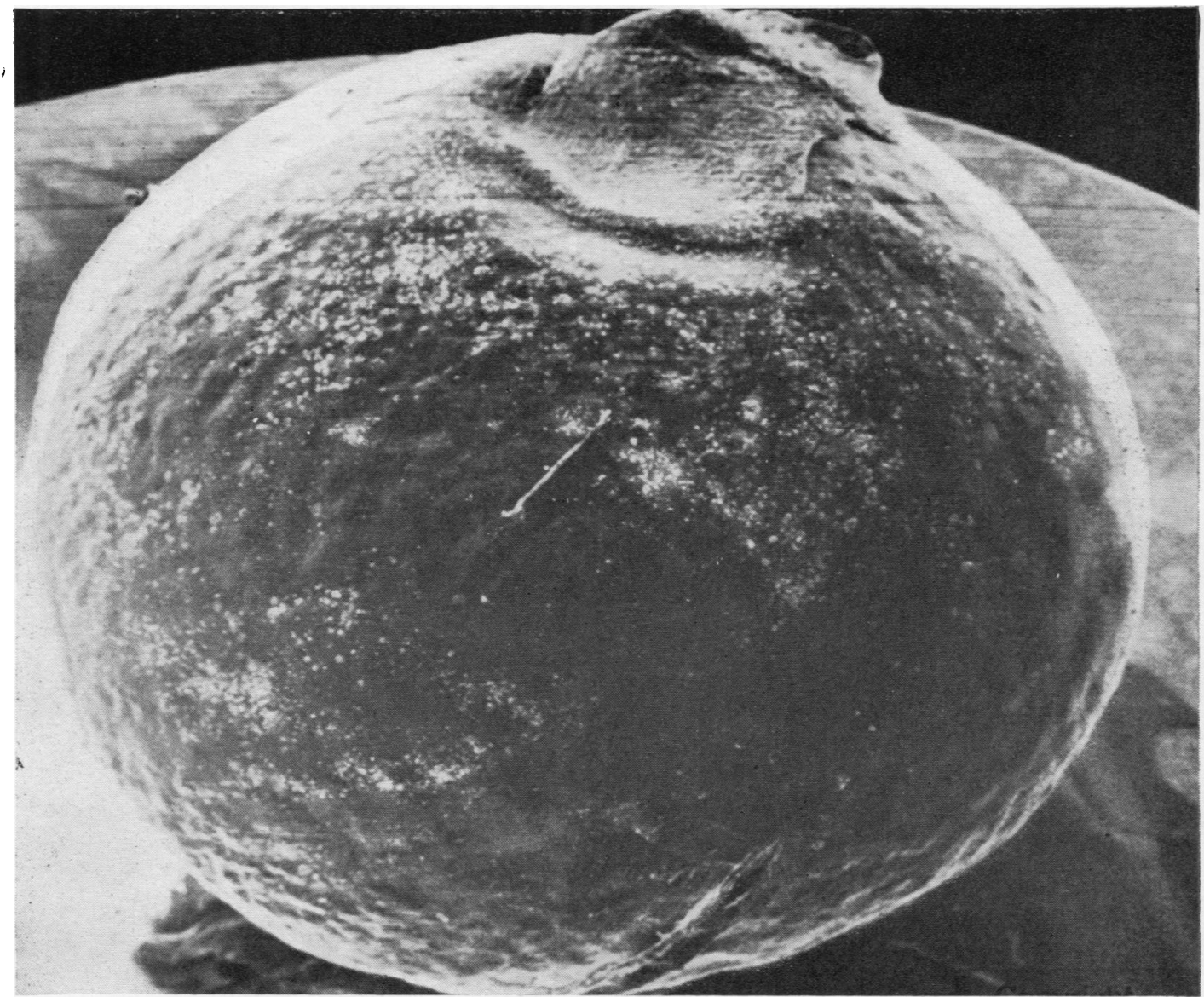

Fig. 2. -Femoral head. Scanning electron microscope view, showing ligamentum teres (top) and dimpled surface of fixed dried specimen. $\times 33$.

concealed by the persistence of surface material (Fig. 3) which was interpreted as of synovial fluid origin but which possibly included cellular material or cell debris. The general pattern of the hollows or craters observed at this magnification led to the suggestion that the surface resembled that of a golf ball.

When limited areas of the golf ball-like surface were examined at much higher magnification (Fig. 4) the presence of the hollows could still be easily recognized but a fine linear arrangement of orientated striations or fibres was detected. The appearance suggested that an orderly array of fibres near, but not at, the articular surface was enmeshed among homogeneous interfibrillar material. Upon the surface were scattered attenuated thread-like stellate deposits which were believed to represent residual synovial fluid and cell debris.

\section{Replica Studies}

Comparable surfaces were investigated by a replica technique. The presence of an orderly pattern of replicated fibres similar in size to those recognized by scanning microscopy was suggested (Fig. 5) and bearing fin-like lateral projections. Adjacent replicated articular surfaces displayed fibre patterns orientated in different directions. However, all parts of the joint surfaces investigated did not reveal the same appearance, and marginal lateral areas of the patellar surface of the femur displayed a less regular pattern of ridges distinct from the fibres described above (Figs 6 and 7).

Replicas of the principal articulating surfaces of the tibia studied at high magnification (Fig. 8) confirmed the suggested fine pattern of hollows and prominences but revealed in greater detail an irregular 


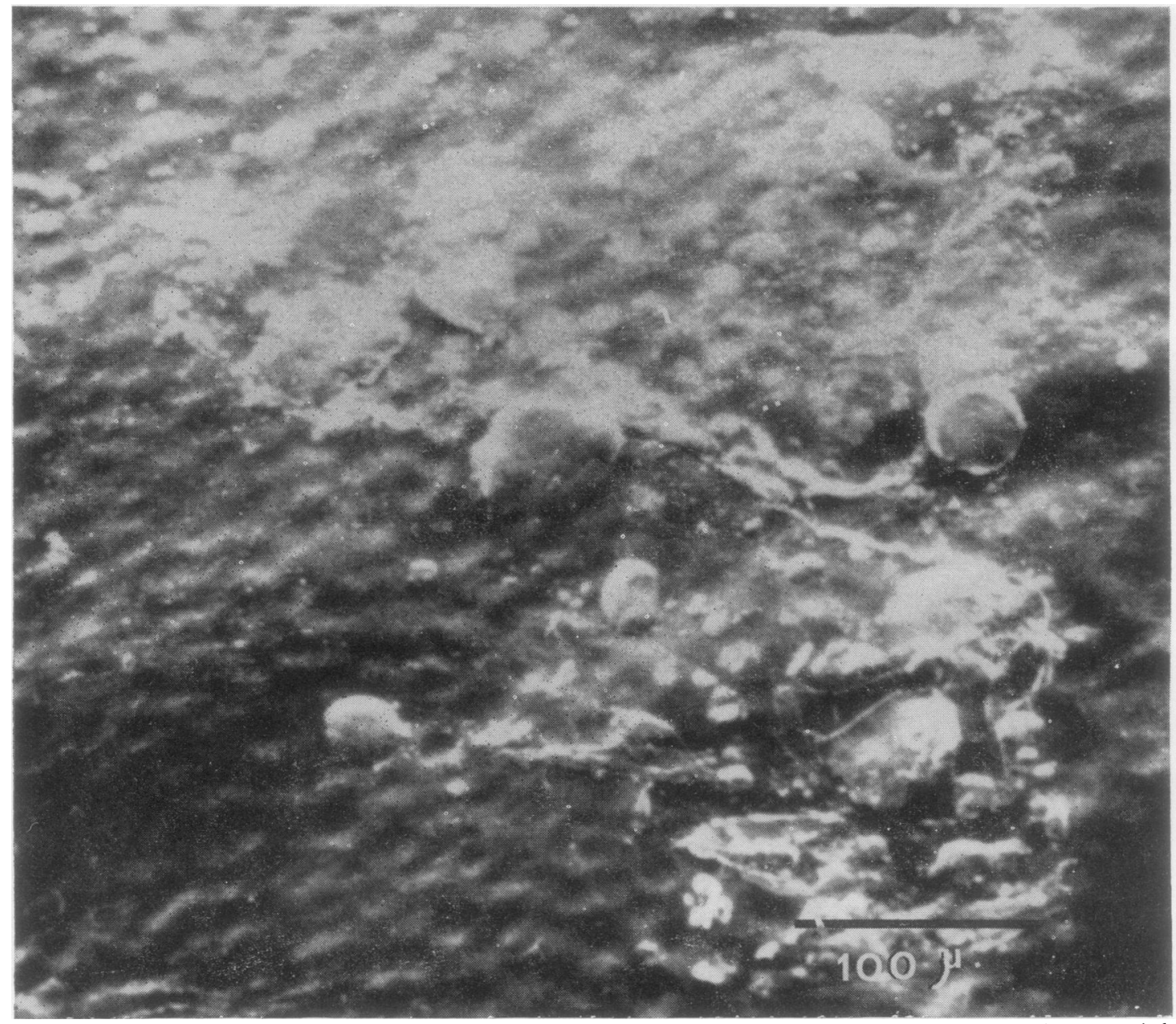

Fig. 3.-Tibial condyle. The load-bearing surface of the tibia displays broad hollows approximately 100-200 $\mu$ in diamster and the much smaller prominences and hollows recognized by light microscopy on the surface of the femoral head (Fig. 1 ). $\times 300$.

reticulated background. They did not always show evidence of the orientated arrangement of fibres (Fig. 5) found on the patellar surface of the femur.

When the articular surfaces were exposed briefly to the action of hyaluronidase before fixation, replicas made from the digested surface (Fig. 9) revealed with much greater clarity the presence of numerous fibrils, many having a fine $250 \AA$ periodic structure. The fibrils were not arranged in recognizable bundles but a resemblance to collagen was suggested. In areas where there had apparently been stripping of the replica surface, the fibril replicas were absent and the surface assumed a laminated character.

\section{Discussion}

Information concerning the three-dimensional structure of the articular surfaces of mammalian synovial joints is now beginning to accumulate (McCall, 1968; Walker, Dowson, Longfield, and Wright, 1968; Walker, Sikorski, Dowson, Longfield, Wright, and Buckley, 1969). In searching for an interpretation of the appearances described in the present paper it is necessary to emphasize that the detailed three-dimensional structure is likely to vary considerably in different joints and even within different areas of a single joint (Gardner and Woodward, 1968). Precise spatial definition of zones selected for study is therefore essential before the reports of different workers can be easily compared. In addition to the problem of selection, a matter which can be overcome by using fully the very large range of magnification of the scanning electron microscope, interpretation of scanning photographs must allow for the introduction of artefacts by the 


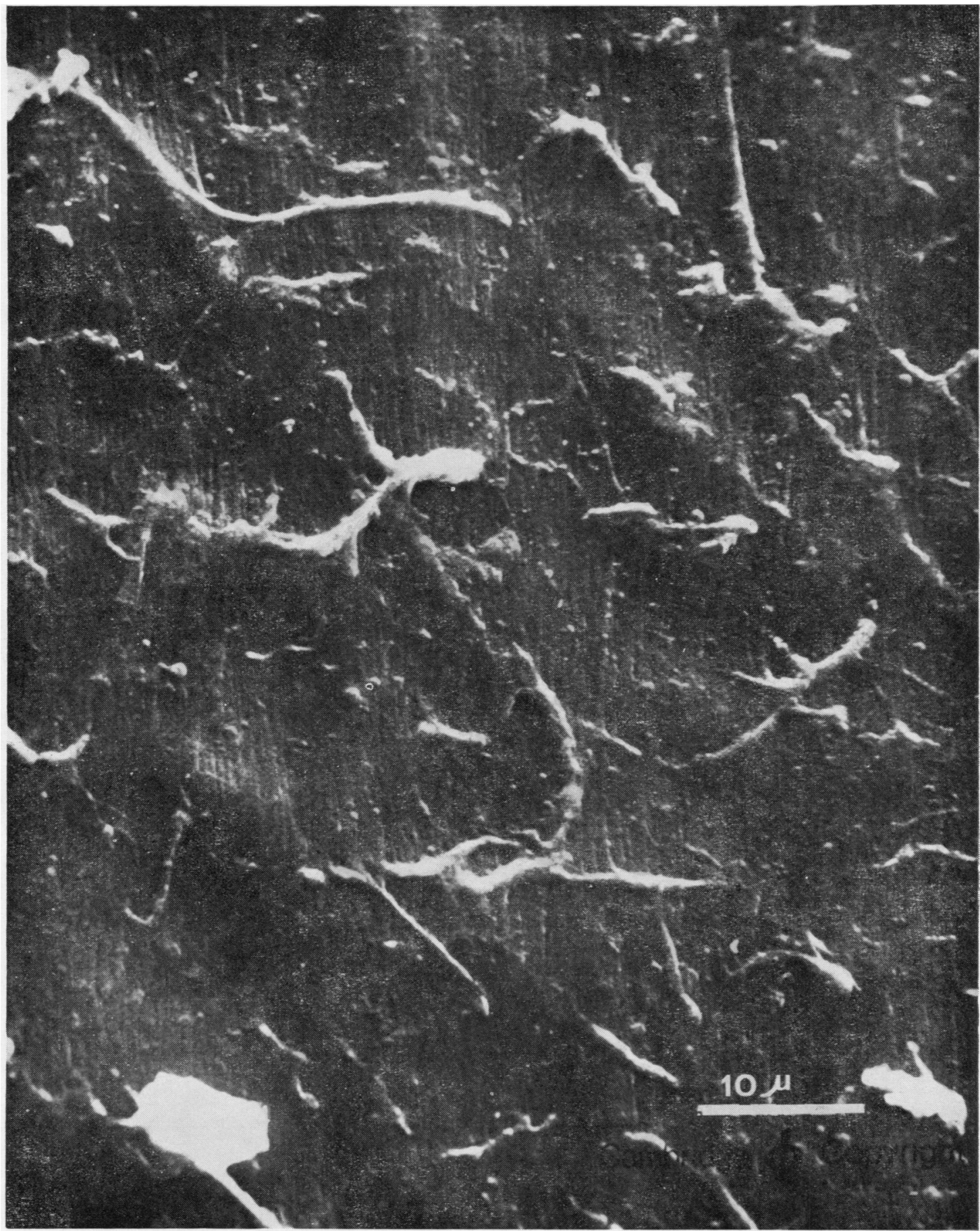

Fig. 4.-Patellar surface of femur. Scanning electron microscopy reveals a gently undulating surface with alternating hollows and prominences, corresponding to those seen at a much lower magnification in Fig. 3 . The surface bears an orderly pattern of orientated striations, possibly corresponding to numerous underlying fibres embedded in a non-fibrous matrix. On the surface rest delicate stellate deposits of altered synovial fluid. $\times 2,500$. 


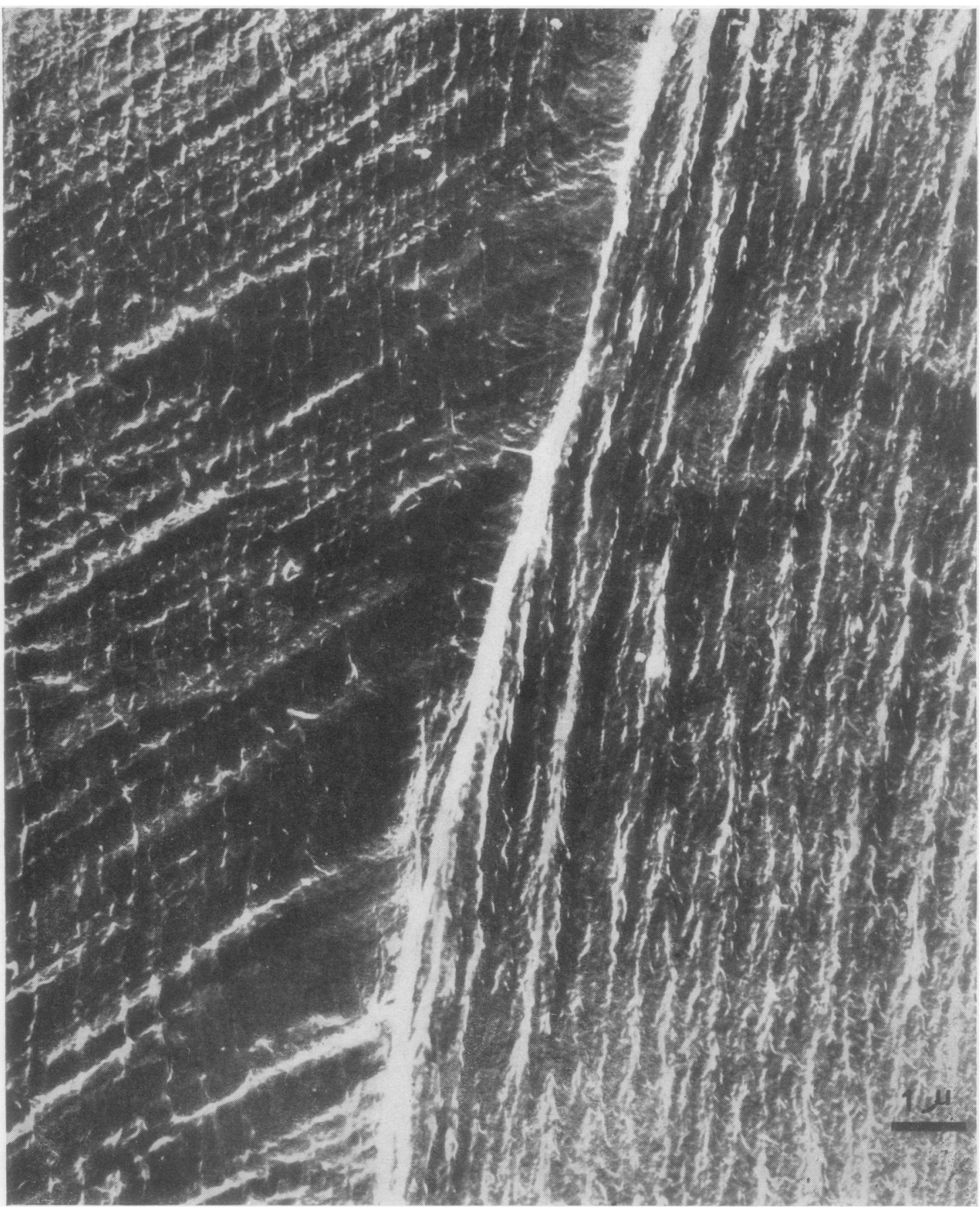

Fig. 5.-Patellar surface of femur. Two-stage replica showing adjacent articular surfaces each marked by numerous parallel ridges corresponding in size to those shown by another method in Fig. 4 . From these parallel ridges spring many fine lateral fins which may represent a second lamina of fibres lying above the first. The broad vertical line is not a fold in the replica. $\times 11,000$ 


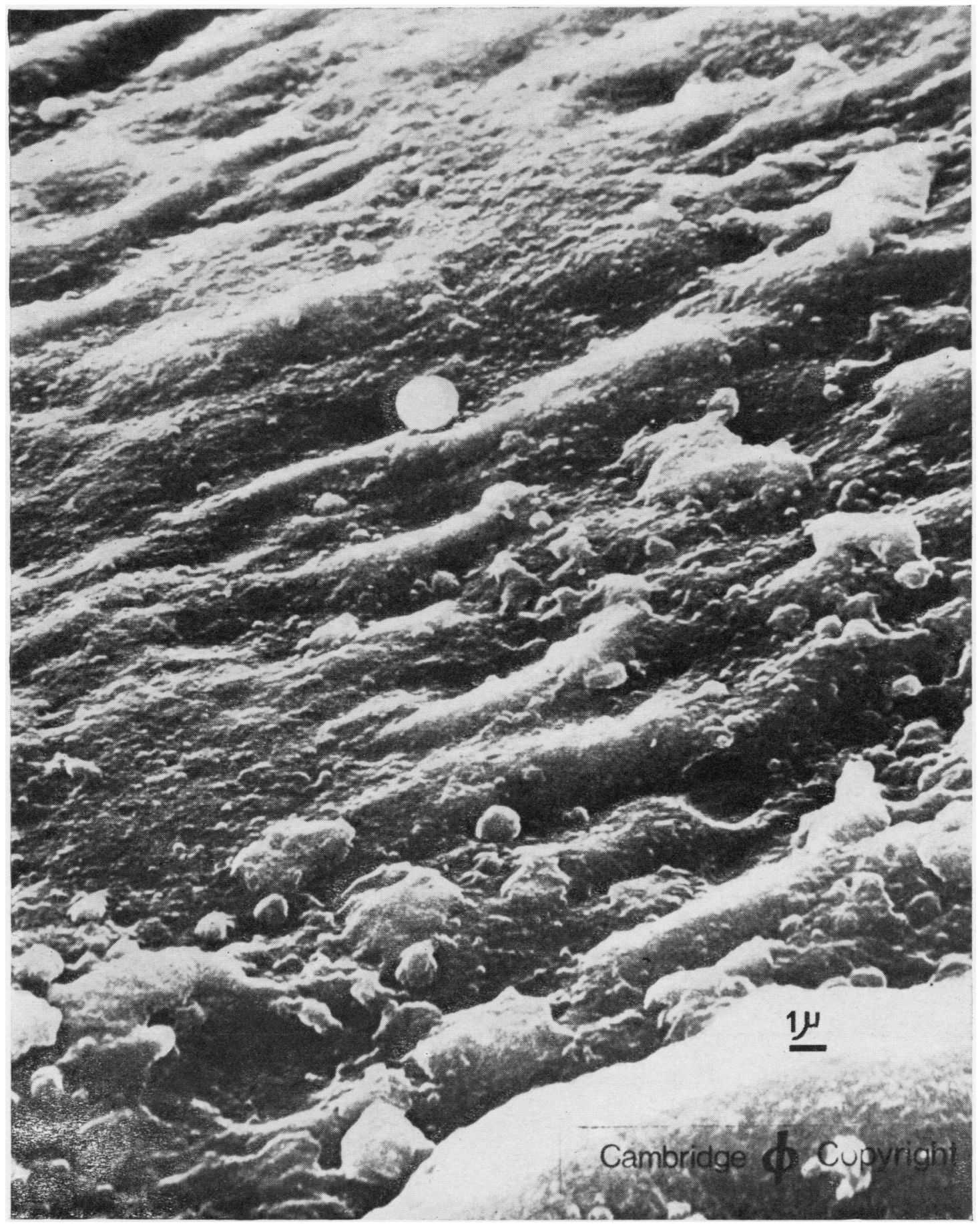

Fig. 5.- Patellar surface of femur. An area near the top of the patellar groove. The fine striations illustrated in Figs. 4 and 5 are not seen; instead, there are broader ridges with aggregates of what is probably altered synovial fluid lying on the articular surface. These ridges run at rigit angles to those shown in the previous illustrations. $\times 5,000$. 


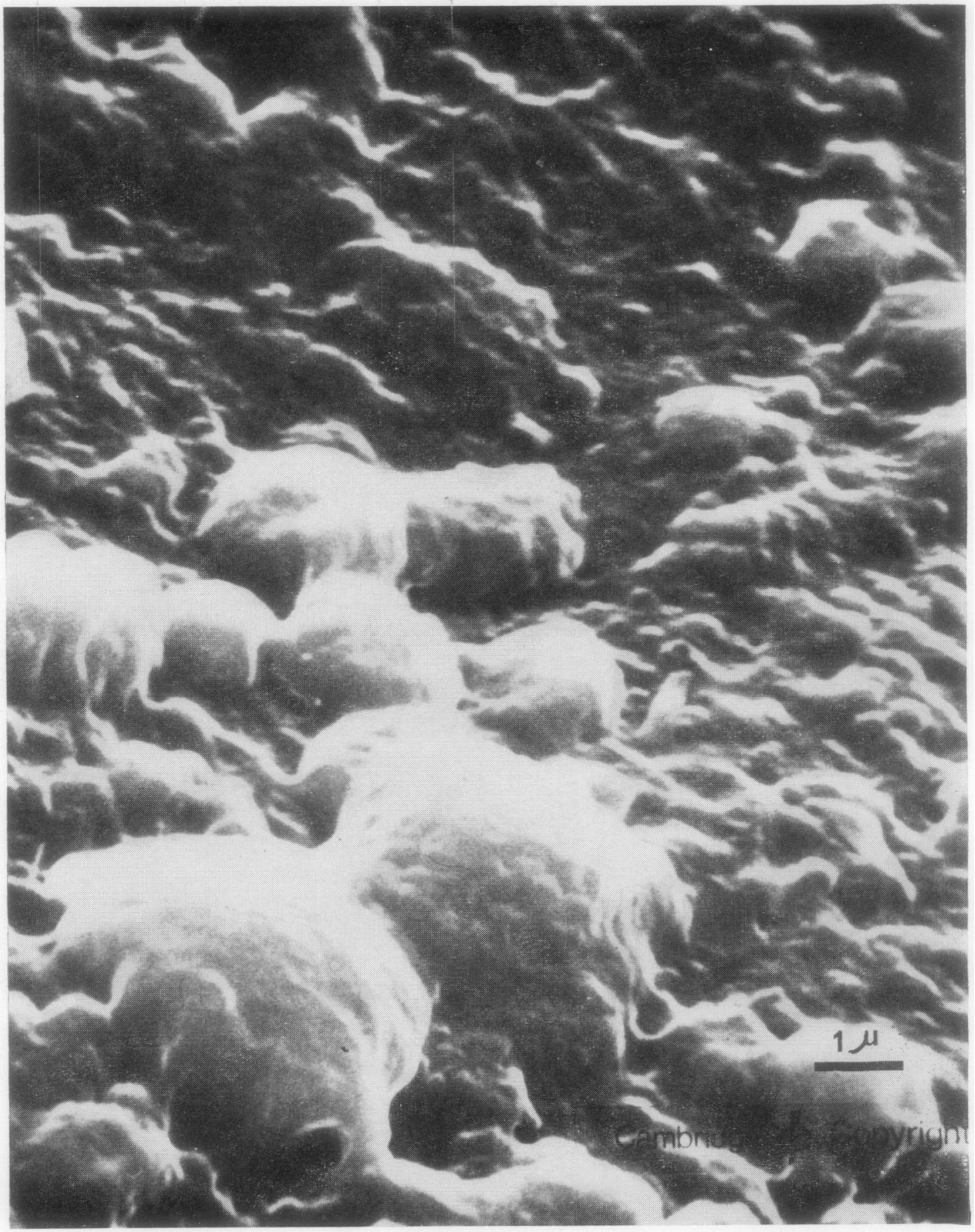

Fig. 7.- Patellar surface of femur. A different part of the upper margin of the femoral articulating surface shown in Fig. 6 at higher magnification. This photograph was made to investigate any possible drying effects not recognized in the surface view (Fig. 6). No such effects were identified. $\times 13,500$. 


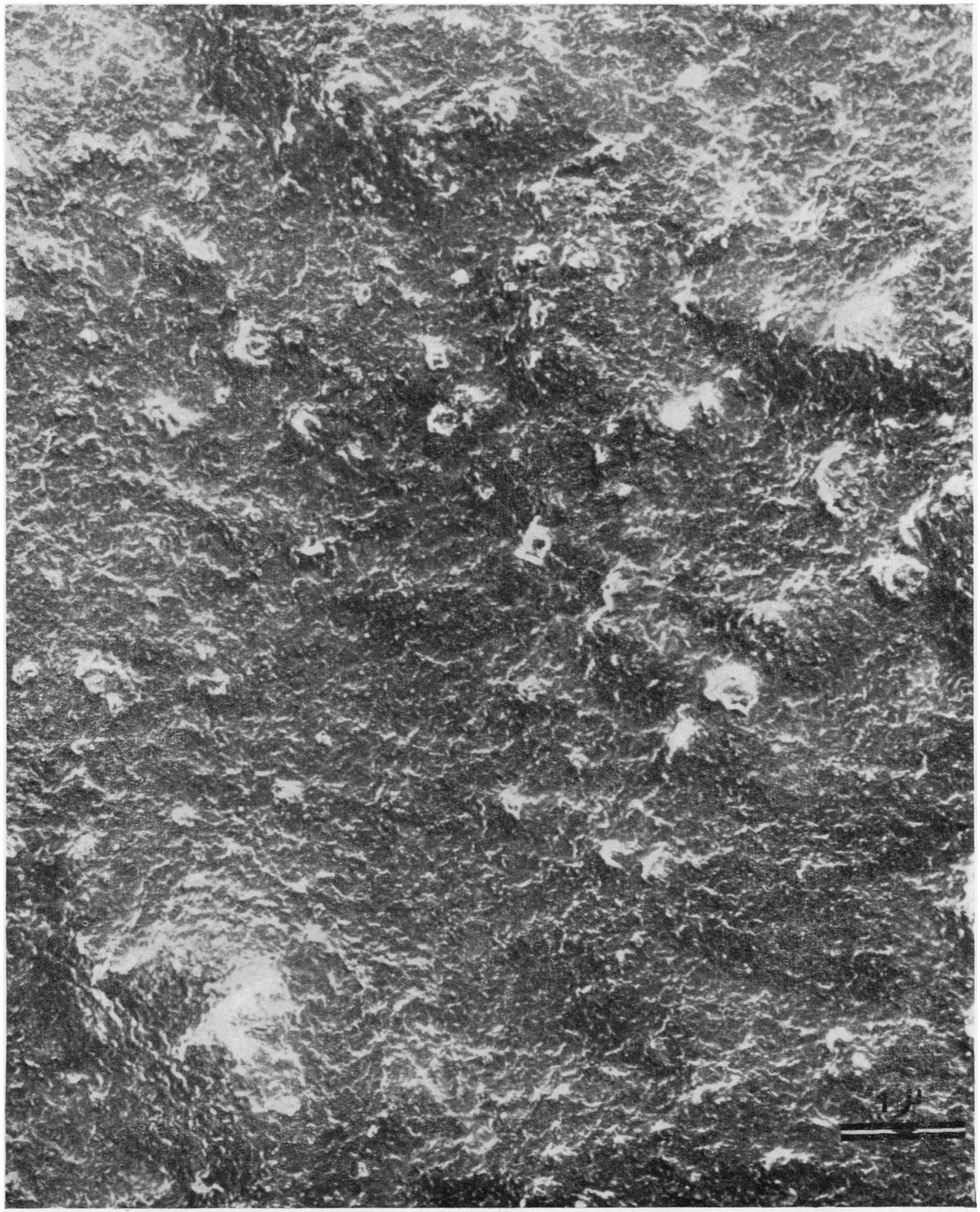

Fig. 8.-Tibial condyle. Reulicas of the articulating surface allow the resolution of much finer detail than is defined by scanning microscopy. In this field the whole area of the photograph is smaller than the depressions seen in Figs. 2 and 3 . Compare with Fig. 7 . Fine irregularities are revealed but they are not orientated. $\times 18,000$ 


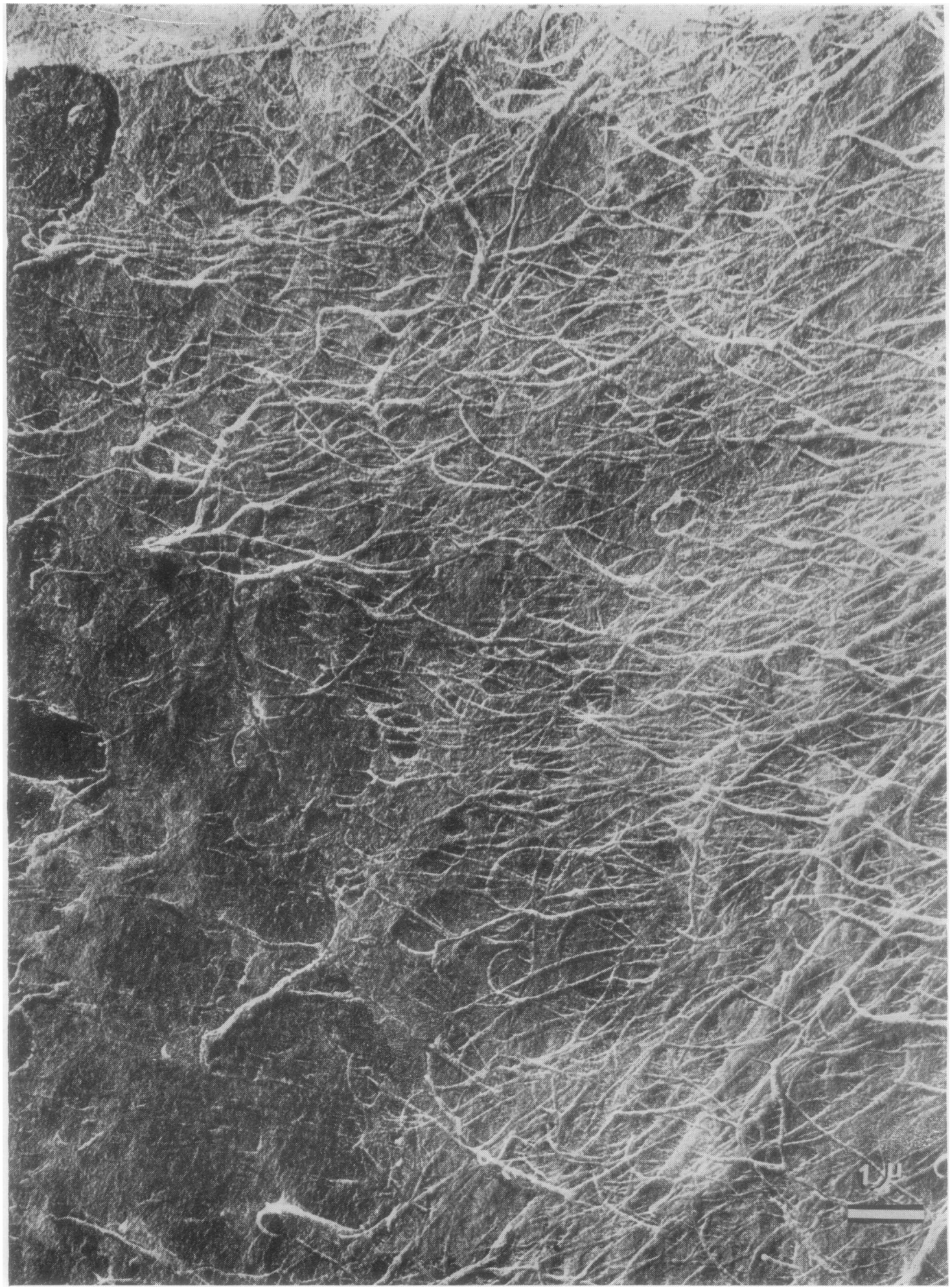

Fig. 9.--Tibial condyle of arthritic knee. The surface was subjected to $15 \mathrm{~min}$. digestion by hyaluronidase ('Hyalase'). This guinea-pig joint was the site of an arthritis caused by the intra-articular injection of bovine $\gamma$-globulin into the knee of a sensitized animal. A reticular foint was the sattern is revealed and the periodic structure shown in the replica suggests that the fibrous pattern is of collagen, loosened and
fibrous subsequently disorientated because of enzyme action. The laminated folds seen at left are probably a result of stripping of the replica surface. $\times 12,800$. 
drying and coating procedures needed for the practice of this technique.

In the present work, the evidence of joint surface structure gained with the scanning microscope has been supplemented by incident light microscopy. However, the possibility of investigating replicas of the articular surfaces by transmission electron microscopy has provided an additional check on possible artefacts. The available evidence shows that broad dimples and smaller hollows can be seen both by light and by scanning microscopy. The existence of a fine background of orientated fibres immediately beneath the surface is likewise suggested both by scanning microscopy and by the study of surface replicas. The studies of Walker, Sikorski, Dowson, Longfield, and Wright (1968) have been based on a method in which a loaded human cartilage surface was very rapidly frozen, and it is important to note that the hollows and prominences described in the present paper appear similar to those demonstrated by this entirely distinct technique.

It is particularly difficult to relate the appearances obtained in these investigations to those derived from the study of sections of articular cartilage prepared for light or electron microscopy. Collagen fibres are known to be present in considerable numbers in the cartilage immediately beneath the joint surface and this conforms with the information gained in the present investigation. No definite evidence was obtained which permits the sites of subarticular chondrocytes to be recognized with certainty in surface scans, but it is possible that the fine hollows and prominences $20-30 \mu$ in diameter described in the present paper represent the sites of broad, flattened, superficial chondrocytes.

It would appear unwise, in the present state of knowledge, to attempt to relate the appearances defined in the present investigation to current theories of the lubricating action of synovial fluid. However, if it is assumed that the small surface hollows and prominences are not artefacts due to drying during preparation, then it may be valid to speculate that the hollows could retain trapped pools of synovial fluid, a suggestion which could influence the interpretation placed upon measurements of the efficiency of lubrication of synovial articular surfaces (Maroudas, 1967; Freeman, Maroudas, and Swanson, 1968).

Support for this suggestion has been obtained from the observations of Walker, Dowson, Longfield, and Wright (1968), who speculated that the high values which they demonstrated for the viscosity of synovial fluid under load might be accounted for by fluid entrapment between irregularities of the cartilage surface.

Some evidence has been obtained, by the use of hyaluronidase, that digestion of the matrix of the cartilage surface can be used to expose intercellular collagen; the pattern of this surface arrangement of fibrils is perhaps better suggested by the scanning microscope and by the use of replicas of non-digested surfaces than by replication after hyaluronidase digestion, since replication of the treated surface probably causes some distortion. However, in a number of preliminary studies, comparing replicas of digested normal guinea-pig cartilage with those of surfaces pre-treated with hyaluronidase, it appeared that articular surface matrix from inflamed joints was removed more easily than the matrix of normal joints. In a subsequent investigation, therefore, which will extend the study of mammalian articular surfaces to other species, it is planned that the relationship between experimental arthritis and susceptibility to hyaluronidase digestion will be analyzed in greater detail.

\section{Summary}

The articular surfaces of the tibia and femur of normal guinea-pigs have been studied by light microscopy and by scanning electron microscopy. Observations made in this way have been compared with the results of transmission electron microscopy of surface replicas made by a 2-stage casting technique.

At low magnification, the articular surface of the guinea-pig femur displayed numerous shallow dimples of about $400 \mu$ diameter. Superimposed on these, and recognized at higher magnification, were many randomly arranged round and ovoid hollows and prominences of 20-40 $\mu$ diameter. Scattered deposits of altered synovial fluid were found upon the articular surfaces in which, in some places, an orientated pattern of fine elongated fibres was recognized both by scanning electron microscopy and by the study of surface replicas.

At high resolution, replicas revealed, in addition, an irregular background of reticular character. When similar replicas were made of surfaces digested briefly with hyaluronidase, the outline of many irregularly arranged microfibrils was identified; these fibrils displayed a recognizable periodic structure recalling that of collagen and the conclusion was reached that surface collagen had been unmasked by the enzymatic digestion of intercellular cartilage 
matrix. The surfaces of joints which were the site of experimental hypersensitivity arthritis proved more susceptible to this action of hyaluronidase than did those of normal guinea-pig cartilage.
The use of the Cambridge Instrument Company's facilities is gratefully acknowledged.

Mr. Paul Warden, N.C.A., C.D.A., A.I.A.T., Chief Animal Technician, Kennedy Institute, kindly provided help with the biological work.

\section{REFERENCES}

Bradley, D. E. (1954). J. Inst. Metals, 83, 35 (A high-resolution evaporated carbon replica technique for the electron microscope).

Dowson, D. (1966). In "Lubrication and Wear in Living and Artificial Joints: A Symposium", Instn. Mech. Engrs Proceedings, 181, 3J, p. 45 (Modes of lubrication in human joints).

Freeman, M. A. R., Maroudas, A., and Swanson, S. A. V. (1968). New Scient., 40, 155 (Joint lubrication).

Gardner, D. L., and Woodward, D. H. (1968). Lancet, 2, 1246 (Scanning electron microscopy of articular surfaces).

Kay, D. H. (ed.) (1965). "Techniques for Electron Microscopy", 2nd ed. Blackwell Scientific Publications, Oxford.

Koonce, S. E., and Berting, F. M. (1956). Bell Lab. Rec., 34, 336 (Electron microscopy of ceramics).

McCall, J. G. (1968). Lancet, 2, 1194 (Scanning electron microscopy of articular surfaces).

McCutchen, C. W. (1966-67). In "Lubrication and Wear in Living and Artificial Joints: A Symposium", Instn. Mech. Engrs Proceedings, 181, 3J, p. 55 (Physiological lubrication).

Maroudas, A. (1967). In "Lubrication and Wear in Living and Artificial Joints: A Symposium", Instn. Mech. Engrs Proceedings, 181, 3J, p. 122 (Hyaluronic acid films).

Nalon, I. M. (1959). Personal communication.

Walker, P. S., Dowson, D., Longfield, M. D., and Wright, V. (1968). Ann, rheum. Dis., 27, 512 ("Boosted lubrication" in synovial joints by fluid entrapment and enrichment).

—, Sikorski, J., Dowson, D., Longfield, M. D., and Wright, V. (1968). Proceedings of the Heberden Society, Nov. 15 (Behaviour of synovial fluid on articular cartilage).

$-, \overline{\text { fluid on surfaces of articular cartilage). }}, \overline{\text {, and Buckley, }}$ T.

L'exploration au microscope électronique et l'étude des reproductions des surfaces articulaires des cobayes

\section{RÉSUMÉ}

Les surfaces articulaires du tibia et du fémur des cobayes normaux ont été étudiées au microscope optique et au microscope électronique. Les observations obtenues de cette façon ont été comparées aux résultats de transmission obtenus au microscope électronique des reproductions des surfaces préparées par la technique de moulage en deux temps.

A un grossissement faible, la surface articulaire du fémur du cobaye montrait de nombreuses fossettes peu profondes d'un diamètre d'à peu près $400 \mu$. Surimposés sur ces fossettes et reconnus à un plus fort grossissement se trouvaient beaucoup de creux ronds et de forme ovoide et des proéminences d'un diamètre de 20 à $40 \mu$ placées au hasard. Des dépôts disséminés de liquide synovial altéré ont été trouvés sur les surfaces articulaires dans lesquelles, à certains endroits, un motif orienté de fibres fines et allongées était reconnu aussi bien par
Microscopia electrónica y estudios duplicados de las superficies articulares de las articulaciones sinoviales del conejillo de Indias

\section{Sumario}

Las superficies articulares de la tibia y del fémur de conejillos de Indias normales han sido estudiadas mediante microscopia óptica y microscopia electrónica. Las observaciones realizadas de este modo han sido comparadas con los resultados de la microscopia electrónica de superficies duplicadas hechas mediante una técnica de moldes en dos etapas.

A poca amplificación, la superficie articular del fémur del conejillo de Indias mostraba numerosos hoyos poco profundos de aproximadamente $400 \mu$ de diámetro. Superimpuestos sobre los hoyos, y reconocidos a mayor amplificación, había numerosas cavidades y prominencias redondas y ovoides, dispuestas al azar, de 20-40 $\mu$ de diámetro. Se hallaron, diseminados, depósitos de fluido sinovial alterado sobre las superficies articulares, en las cuales, en algunos lugares, se identificó un esquema 
l'exploration au microscope électronique que par l'étude des reproductions des surfaces.

A un fort grossissement, les reproductions ont révélé, de plus, un fond irréguliér d'un caractère réticulaire. Quand le semblables reproductions ont été faites des surfaces légèrement digérées par l'hyaluronidase, le tracé de plusieurs microfibrilles arrangées irrégulièrement avait été identifié; ces fibrilles montraient une structure périodique reconnaissable rappelant celle du collagène et il a été conclu que le collagène de surface avait été démasqué par la digestion enzymatique de la substance fondamentale du cartilage. Les surfaces des articulations qui étaient l'endroit de l'arthrite provoquée par hypersensibilisation se sont averées plus susceptibles à cette action de l'hyaluronidase que celles du cartilage du cobaye normal. orientado de fibras finas, alargadas, tanto por medio de la microscopia electrónica como por el estudio de los duplicados.

A alta amplificación, los duplicados revelaron, además, un fondo irregular de carácter reticular. Cuando se hicieron duplicados similares de superficies digeridas brevemente con hialuronidasa, se identificó el contorno de numerosas microfibrillas dispuestas de manera irregular; estas fibrillas presentaban una estructura periódica identificable, parecida a la del colágeno, y se llegó a la conclusión de que la superficie colagenosa había quedado al descubierto por la digestión enzimática de la matriz cartilaginosa intercelular. Las superficies de articulaciones que eran objeto de poliartritis hipersensitiva experimental resultaron ser más susceptible a esta acción de la hialuronidasa que las del cartílago de un cobayo normal. 